\title{
Dinsel Yaşayış Ölçeği: Geçerlik Güvenirlik Çalışması
}

\author{
Prof. Dr. Hasan KAYIKLIK*
}

Mehmet Emin KALGl ${ }^{* *}$

Atıf / @-- Kayıklık, H.- Kalgı, M. E. (2017). Dinsel Yaşayış Ölçeği: Geçerlik Güvenirlik Çalışması, Çukurova Üniversitesi Illahiyat Fakültesi Dergisi, 17 (1), 1-19.

Öz- Bu çalışmanın amacı, daha önce Kayıklık (2003) tarafından geliştirilen "Dinsel Yaşayış Ölçeği"ni revize etmektir. Revize sürecinde ölçeğin faktör sayısı (3 faktör) aynen korunmuş, fakat ölçeğe yeni maddeler eklenerek ve uzman görüşleri doğrultusunda bazı maddelerde değişiklik yapılarak ölçeğin hem geçerlilik için açımlayıcı ve doğrulayıcı faktör analizi yapılmış hem de güvenirlik analizi için iç tutarlıklık (cronbachalpha) katsayısı hesaplanmıştır. Çalışmada nicel araştırma yöntemlerinden biri olan genel tarama modeli kullanılmıştır. Çalışmanın verileri, Şanlıurfa'nın Siverek ilçesinin Karacadağ Anadolu Lisesinde okuyan ve basit tesadüfí yöntemle seçilen 158 (103 kIz, 55 erkek) öğrenci üzerinden alınmıştır. Dinsel Yaşayış Ölçeğini (DYÖ) oluşturan maddelerin açımlayıcı faktör analizinde faktör ortak varyans değerlerinin 0.262-0.960 ve döndürülmüş faktör yük değerlerin 0.390-0.970 arasında değiştiği görülmüştür. Ayrıca DYÖ için yapılan doğrulayıcı faktör analizinde modelin uyum indekslerinden birisi olan $X^{2} /$ sd'nin değeri 1.93, NFI değeri 0.91, NNFI değeri 0.95, CFI değeri 0.95 ve SRMR değeri 0.07, RMSEA değeri 0.07 olduğu görülmüştür. Ölçeğin güvenirlik analizi için iç tutarlılık katsayısı hesaplanmıştır. Buna göre, ölçek maddelerinin iç tutarlık katsayısı 0.930 olarak bulunmuştur. Ayrıca Faktör-1, Faktör-2 ve Faktör-3'ün iç tutarlılık katsayısı sırasıyla 0.982, 0.937 ve 0.875 olarak bulunmuştur. Ölçekteki her bir ifade 7'li likert tipi derecelendirme ile yapılmakta ve her maddeye en düşük bir (1) en yüksek yedi (7) puan verilerek hesaplanmıştır. Buna göre otuz altı (36) maddelik DYÖ'de bir kişinin alabileceği en düşük puan otuz altı (36), en yüksek puan ise iki yüz elli iki (252)'dir. Kişi ölçek ortalamasının üstünde bir puan alabiliyorsa dindar olarak değerlendirilmektedir.

Anahtar sözcükler- Dinsel yaşayış ölçeği, geçerlik, güvenirlik, inanç, ibadet, ahlak

\section{$\S \S \S$}

Makalenin gelişi: 17.05.2017; Yayına kabul tarihi: 19.06.2017

* Çukurova Üniversitesi İlahiyat Fakültesi Din Psikolojisi Anabilim Dalı öğretim üyesi, e-posta: hkayiklik@cu.edu.tr

** Çukurova Üniversitesi Sosyal Bilimler Enstitüsü Felsefe ve Din Bilimleri Anabilim Dalı (Din Psikolojisi) Doktora Öğrencisi, e-posta: mehmet.emin.63.21@gmail.com 


\section{Giriş}

Din ve dindarlık konuları insan psikolojisiyle yakından ilişkili olduğu için bilim adamlarınca araştırılan konuların başında gelir. Bu kavramların bilimsel literatürde kullanılmaları önceleri teorik bilgilere dayanmış olsa da ilk saha çalışmalarına yabancı literatürde 1940 'larda ve Türkiye'de ise 1980 'lerde rastlanmaktadır (Onay, 2001:439).

Dindarlık, farklı şekillerde ölçülebildiği için gerek yabancı literatürde (Beckwith ve Morrow, 2005; Cotton, Larkin, Hoopes, Cromer, Rosenthal, 2005; Hyman ve Handal, 2006; Almeida, Neto ve Koenig, 2006) ve gerekse de Türk literatüründe (Uysal, 1996; Cirhinlioğlu, 2010; Hökelekli, 2010; Kayıklık, 2011; Peker, 2011; Tarhan, 2013; Murata\&Chittick, 2012; Şentürk, 2013; Yavuz, 2013; Yapıcı; 2013; Hökelekli, 2013) tanımsal olarak da farklılaşmaktadır. Dindarlığın farklı tanımlamasındaki nedenlerin başında kavramın sübjektif (Uysal, 1996) yargılar içermesi yer almaktadır. Çünkü kurumsallaşmış veya kurumsallaşmamış her din, müntesiplerine farklı kurallar çerçevesi çizer.

Tek tanrılı dinlerde bile dine yüklenen anlamda farklılaşma olduğu için ortak bir dindarlık tanımı yapılamamaktadır (Yapıcı, 2013:7). Çünkü yapılan dindarlık tanımları kişinin aidiyet hissettiği dine, mezhebe, mesleki durumuna, cinsiyetine vb. psiko-sosyal durumlarına göre değişebilmektedir.

\section{Literatür Taraması}

Bu çalışmanın kavramsal çerçevesini oluştururken din ve dindarlık tanımlarından daha çok bu kavramların farklı tanımlaması üzerinde duruldu. Bununla beraber Türkiye'de geliştirilen ve uyarlanan dindarlık ölçeklerinin durumunu tespit etmek de önemlidir.

Ülkemizde dindarlık ölçmeye yönelik ulaşabildiğimiz kadarıyla ilk girişim Tablamacıoğlu (1962) tarafından yapılmıştır. Fakat Tablamacıoğlu (1962) tarafından yapılan bu çalışma, dindarlığa yönelik ölçek olarak geliştirmekten daha çok farklı dindarlık görüntülerini ortaya koymaktan ibarettir. Benzer şekilde bir başka çalışma da Fırat'ın (1977) doktora çalışmasında kullanılmak üzere anket olarak hazırlamıştır (Mutlu, 1989). Bu çalışmaların geçerlilik ve güvenirlik analizleri yapılmadığı için bilimsel anlamda birçok eksiklik barındırmaktadır. Müslüman dindarlık ölçümü ile ilgili istatistiksel analizleri yapılmış ölçeklerin Türkiye'de kullanılması 1980'lere dayanmaktadır (Onay, 2001:439). Bunlardan biri Mutlu (1989) tarafından "İslami Dindarlık Ölçeği" adıyla geliştirilmiş ve geliştirilen bu ölçeğin güvenirlik katsayısı (cronbach-alpha) 0.94 olarak bulunmuştur. Daha sonra Köktaş (1993), dindarlığı ölçmeye yönelik bir 
çalışma yapmış ve yapmış olduğu bu çalışma beş faktörlüdür. Fakat Köktaş'ın (1993) çalışmasında gerekli istatistiksel analizler yapılmadığı için dezavantajlı olarak değerlendirilmektedir (Onay, 2001:443).

Uysal (1995) "İslami Dindarlık Ölçeği" adlı çalışmasının faktörleşmesinde Glock'un beş faktör modelini esas almış ve bunu üniversite ortamında çalışan 439 kişi üzerinde uygulayarak ölçeğin iç tutarlıık katsayısını 0.97 olarak hesaplamıştır.

Kayıklık (2000), Allport tarafından geliştirilen iç ve dış güdümlü dindarlık ölçeğini Türkçe'ye uyarlayarak bu alana büyük katkı sağlamıştır. Yine Türkiye'de birçok araştırmacı dini yönelim, yaşayış, tutum, gibi birçok konuda ölçek geliştirme ve uyarlama çalışması yapmıştır. Bunlar; Kaya (1998) "Dini Tutum Ölçeği, Yapıcı (2002) "Dini Dogmatizm Ölçeği", Türküm (2003) "Akılcı Olmayan İnanç Ölçeği", Kayıklık (2003) "Dini Yaşayış Ölçeği", Onay (2004) "Dini Yönelim Ölçeği", Yapıcı (2006) "Dinin Etkisini Hissetme Ölçeği", Yıldız (2006) "Dini Hayat Ölçeği", Arslan (2010) "Paranormal İnanç Ölçeği", Ok (2011) "Ok-Dini Tutum Ölçeği" şeklinde sıralanabilir.

Şu an Türkiye'de kullanılan ve ulaşabildiğimiz dindarlık ölçekleri kavramsal çerçeve içerisinde verilmeye çalışılmıştır. Türkiye'de geçmişten günümüze dindarlığı ölçmeye yönelik yapılan çalışmalarda büyük bir artış yaşandığı görülmektedir (Uysal, 1995:263). Fakat bu artış istenen seviyede değildir. Bu anlamda bu çalışma, alana katkı sağlaması beklenmektedir.

\section{Yöntem}

Çalışmada nicel araştırma yöntemlerinden genel tarama modeli kullanılmıştır. Genel tarama modeli, çok sayıda elemandan oluşan bir evrende, evren hakkında genel bir yargıya varmak amacıyla evrenin tümü ya da ondan alınacak bir grup, örnek ya da örneklem üzerinde yapılan tarama düzenlemeleridir (Karasar, 2004:79).

\subsection{Evren ve Örneklem}

Araştırmanın evrenini, Şanlıurfa/Siverek ilçesinin ortaöğretim öğrencileri ve örneklemi ise bu okullardan basit tesadüfî yöntemle seçilmiş olan 158 öğrenci oluşturmaktadır. Örneklemin seçilmesinde farklı demografik özellikler (yaş, cinsiyet, gelir düzeyi) taşıyan öğrencilerin bulunması amaçlanmıştır. Katılımcıların demografik özelliklerine ait bilgiler şu şekildedir: a) cinsiyet: Kız \%65.2 (103), Erkek \%34.8 (55); b) yaş: $14 \% 19$ (30), $15 \% 38.6(61), 16 \% 8.9$ 
(14), $17 \% 17.1(27), 18 \% 16.5(26)$; c) ailenin aylık gelir düzeyi: Ortanın altı $\% 12$ (19), Orta \%86.1 (136), Ortanın üstü \%1.9 (3) şeklindedir.

\subsection{Veri Toplama}

Çalışmada, nicel veri toplama aracı kullanılmıştır. Nicel veri toplama aracı olarak daha önce Kayıklık (2003) tarafından geliştirilen "Dinsel Yaşayış Ölçeği" kullanılmıştır. Kayıklık (2003) tarafından geliştirilen ölçeğin özgün formu için inanç boyutu üçlü likert tipinde 11 madde, ahlak boyutu dörtlü likert tipinde 9 madde ve ibadet boyutu dörtlü likert tipinde 15 madde olmak üzere toplam 3 boyut ve 35 maddeden oluşmaktadır. İnanç boyutu maddeleri "KatıIıyorum (3), Kararsızım (2), Katılmıyorum (1)" şeklinde puanlanırken; ahlak ve ibadet boyutu maddeleri ise "Her Zaman (4), Çoğu Zaman (3), Bazen (2), Hiç (1)" şeklinde puanlanmaktadır.

DYÖ'nün revize edilmesi için takip edilen süreçler; maddelerin düzenlenmesi ve madde havuzunun oluşturulması, uzman kişilerin görüşlerine başvurulması, ölçeğin uygulaması ve ölçeğin düzenlenmesi, geçerlik ve güvenirlik analizleri yapılması şeklindedir. Ayrıca geliştirilen DYÖ'nün, geçerlik ve güvenirlik açısından incelenmesi için açımlayıcı faktör analizi, doğrulayıcı faktör analizi, uzman görüşü ve iç tutarlılık katsayısı işlemleri de araştırmacılar tarafından özenle yerine getirilmiştir (Büyüköztürk, 2012; Yılmaz ve Tan, 2016:189; Yılmaz ve Fakirullahoğlu, 2016:226).

\subsubsection{Maddelerin Düzenlenmesi ve Madde Havuzunun Oluşturulması}

Çalışmanın ilk aşamasında Kayıklık (2003) tarafından geliştirilen 35 maddelik DYÖ'nün orijinal soruları esas alınmıştır. Ölçeğin ibadet boyutunun 25. maddesi (Maddi gücüme göre zekâtımı veriyorum) öğrencilerin yaş düzeyi göz önünde bulundurularak ölçekten çıkarılmıştır. Buna göre "Dinsel Yaşayış Ölçeği"nden toplam otuz dört madde alınmıştır. Ayrıca araştırma konusu hakkında derinlemesine literatür taraması yapılmış (Mutlu, 1989; Yapıcı, 2002; Türküm, 2003; Yapıcı, 2006; Arslan, 2010) ve ölçeğe 21 adet standart madde daha eklenmiştir. Bu aşamanın sonunda "Dinsel Yaşayış Ölçeği" ile ilgili 55 maddelik bir anket hazırlanmıştır. Daha sonra kapsam geçerliliği sağlanması için konu alanı uzmanı dokuz (9) öğretim üyesine görüş sorulmuştur. Alınan dönütler çerçevesinde on bir madde [Zayıfları her zaman koruyorum (1), Herkesle iyi geçiniyorum (2), Inancım gereği olan ibadetlerimi yerine getiriyorum (3), Cenaze merasimlerine katılıyorum (4), Mevlit, hatim gibi dinsel toplantılara katılıyorum (5), Hz. Muhammed'e salâvat getiriyorum (6), Gayb âlemi vardır 
(7), Allah sonsuzdur (8), Allah geçmişte olan ve gelecekte olacak her şeyi bilir (9), Öldükten sonra dirilme vardır (10), Hayır ve şer Allah'tandır (11)] ölçekten çıkarılarak 44 maddelik bir ölçek geliştirilmiştir. Bu maddelerin KGO (Kapsam Geçerlik Oranı) ve KGI (Kapsam Geçerlik İndeksi) değerleri Tablo-1'de sunulmuştur.

158 kişi üzerinde uygulanması yapılan ölçeğin açımlayıcı faktör analizinde sekiz madde [Cennet-cehennem diye bir şey yoktur (1), Kuran zaman aşımına uğramıştır (2), Allah'ın var olup olmadığı kesin değildir (3), Aleyhime olsa da her zaman doğruyu söylüyorum (4), Davranışlarımı Allah'ın her yerde beni gördüğü bilinciyle yapmaya gayret ediyorum (5), Maddi gücüm uygun olursa, hacca gitmeyi düşünüyorum (6), Inancım gereği ilim öğreniyorum (7), Allah'ı tefekkür ediyorum (8)] binişik değerlere sahip ve faktör yük değerleri düşük olması nedeniyle analizden çıkarılarak 36 maddelik bir ölçek geliştirilmiştir. Yapılan analizler ve dönütler göz önünde bulundurularak ölçeğin kapsam ve görünüş geçerliliği sağlanmaya çalışılmıştır (Fraenkel ve Wallen, 2003).

Tablo-1. Kapsam Geçerlik Oranı (KGO) ve Kapsam Geçerlik İndeksi (KGi) Sonuçları

\begin{tabular}{|l|l|l|l|l|l|}
\hline $\begin{array}{l}\text { Madde } \\
\text { Numarası }\end{array}$ & $\begin{array}{l}\text { Kapsam Ge- } \\
\text { çerlik } \\
\text { Oranı (KGO) }\end{array}$ & $\begin{array}{l}\text { Madde } \\
\text { Numarası }\end{array}$ & $\begin{array}{l}\text { Kapsam Ge- } \\
\text { çerlik } \\
\text { Oranı (KGO) }\end{array}$ & $\begin{array}{l}\text { Madde } \\
\text { Numarası }\end{array}$ & $\begin{array}{l}\text { Kapsam Ge- } \\
\text { çerlik } \\
\text { Oranı (KGO) }\end{array}$ \\
\hline $\mathbf{1}$ & 0,71 & $\mathbf{1 3}$ & 1,57 & $\mathbf{2 5}$ & 1,29 \\
\hline $\mathbf{2}$ & 1,00 & $\mathbf{1 4}$ & 1,29 & $\mathbf{2 6}$ & 1,29 \\
\hline $\mathbf{3}$ & 1,00 & $\mathbf{1 5}$ & 1,29 & $\mathbf{2 7}$ & 1,29 \\
\hline $\mathbf{4}$ & 1,00 & $\mathbf{1 6}$ & 1,29 & $\mathbf{2 8}$ & 1,00 \\
\hline $\mathbf{5}$ & 1,29 & $\mathbf{1 7}$ & 1,00 & $\mathbf{2 9}$ & 1,00 \\
\hline $\mathbf{6}$ & 1,00 & $\mathbf{1 8}$ & 0,71 & $\mathbf{3 0}$ & 1,00 \\
\hline $\mathbf{7}$ & 1,29 & $\mathbf{1 9}$ & 1,29 & $\mathbf{3 1}$ & 1,29 \\
\hline $\mathbf{8}$ & 1,00 & $\mathbf{2 0}$ & 1,57 & $\mathbf{3 2}$ & 1,29 \\
\hline $\mathbf{9}$ & 1,00 & $\mathbf{2 1}$ & 1,00 & $\mathbf{3 3}$ & 1,00 \\
\hline $\mathbf{1 0}$ & 1,00 & $\mathbf{2 2}$ & 1,57 & $\mathbf{3 4}$ & 1,57 \\
\hline $\mathbf{1 1}$ & 1,00 & $\mathbf{2 3}$ & 0,71 & $\mathbf{3 5}$ & 1,57 \\
\hline $\mathbf{1 2}$ & 1,29 & $\mathbf{2 4}$ & $\mathbf{3 6}$ & 1,29 \\
\hline \multicolumn{6}{|l}{ Kapsam Geçerlik Indeksi (KGi)=1,17 } \\
\hline
\end{tabular}




\subsubsection{Derecelendirme Sisteminin Belirlenmesi}

Standart belirlemeye yönelik yapılan literatür taramasında (Kayıklık, 2003; Yapıcı, 2006; Ok, 2011) 3'lü, 4'lü ve 5'li likert tipi puanlama sistemlerinin kullanıldığı belirlenmiştir. Fakat bu çalışmada, katılımcıların görüşlerini yüksek derecede yansıtması için 7'li likert tipi ölçekleme sistemi kullanılmıştır. Her bir madde için inanç boyutunda ölçekteki ifadelerin puanlanması: "Hiç Katılmıyorum (1), Çok Az Katılıyorum (2), Ender Olarak Katılıyorum (3), Biraz Katılıyorum (4), Oldukça Katılıyorum (5), Genellikle Katılıyorum (6), Tamamen Katılıyorum (7)" şeklindedir. Ahlak ve ibadet boyutları için ölçekteki ifadelerin puanlanması:" Bana Hiç Uygun Değil (1), Bana Pek Uygun Değil (2), Bana Çok Az Uygun (3), Bana Biraz Uygun (4), Bana Oldukça Uygun (5), Bana Genellikle Uygun (6), Bana Her Zaman Uygun (7)" şeklindedir.

\subsection{3. Ölçeğin Uygulanması}

DYÖ'nün uygulanması, 2016-2017 yılında Şanlıurfa'nın Siverek ilçesinin Karacadağ Anadolu Lisesinde eğitim-öğretim gören 158 kişilik bir katıIımcı grubu ile yapılmıştır. Araştırmaya katılan kişilerin gönüllü ve objektif olmaları esas alınmış, ölçek formu dağıtılmadan önce katılımcıların araştırma ve ölçek ile ilgili bilgi sahibi olmaları sağlanmış ve katılımcıların anketlere isimlerini yazmamaları istenmiştir. Uygulamalar ortalama 20 dakika sürmüştür.

\subsection{Veri Analizi}

Nicel veri toplama aracı ile elde edilen veriler SPSS 20.0 ve LISREL 9.2 paket programları kullanılarak analiz edilmiştir. Analizlerde açımlayıcı ve doğrulayıcı faktör analizlerine yer verilmiştir. "Açımlayıcı ve doğrulayıcı olmak üzere iki tür faktör analizi yaklaşımı vardır. Açımlayıcı faktör analizinde, değişkenler arasındaki ilişkilerden hareketle faktör bulmaya yönelik bir işlem; doğrulayıcı faktör analizinde ise değişkenler arasındaki ilişkiye dair daha önce saptanan bir hipotezin ya da kuramın test edilmesi söz konusudur" (Büyüköztürk, 2012:123). Dağlı ve Baysal'a göre, araştırmada temel amaç keşfetmek ise açımlayıcı faktör analizi kullanılmalıdır (2016:1255).

\section{Bulgular}

Yapılan analizler sonucunda elde edilen bulguların anlaşılır bir şekilde sunulması için; "ölçeğin puanlanması", "verilerin faktör analizi için uygunluğu", "açımlayıcı faktör analizi" ve "doğrulayıcı faktör analizi" başlıklaması yapılmıştır. 


\section{1 Ölçeğin Puanlanması}

Güvenirlik ve geçerlik analizleri neticesinde DYÖ, madde yapılarına göre inanç, ahlâk ve ibadet boyutu olmak üzere toplam üç faktör ve 36 maddeden oluşmaktadır.

DYÖ'nün inanç boyutu 12 maddeden oluşmaktadır. İnanç boyutu maddeleri "Hiç Katılmıyorum (1), Çok Az Katılıyorum (2), Ender Olarak Katılıyorum (3), Biraz Katılıyorum (4), Oldukça Katılıyorum (5), Genellikle Katılıyorum (6), Tamamen Katılıyorum (7)" biçiminde 7 seçenekle kodlanmakta ve ölçeğin inanç boyutunda en düşük 12, en yüksek 84 puan alınabilmektedir. Ölçeğin hem ahlâk hem de ibadet boyutları da 12'şer maddeden oluşmaktadır. Bu maddeler, " Bana Hiç Uygun Değil (1), Bana Pek Uygun Değil (2), Bana Çok Az Uygun (3), Bana Biraz Uygun (4), Bana Oldukça Uygun (5), Bana Genellikle Uygun (6), Bana Her Zaman Uygun (7) biçiminde kodlanıp puanlanmaktadır. Buna göre ölçeğin ahlâk ve ibadet boyutlarından alınabilecek en düşük 12, en yüksek ise 84 puandır. Bu değerlendirme sonucunda ölçekte alınabilecek en düşük toplam puan 36 , en yüksek toplam puan ise 252'dir. Bu değerlendirmeyle beraber katılımcılar ortalamanın üstünde bir puan alabiliyorsa dindar olarak değerlendirilmektedir.

\subsection{Verilerin Faktör Analizi İçin Uygunluğu}

Uygulama sonucunda elde edilen verilerin faktör analizi için uygunluğu Kaiser-Meyer-Olkin (KMO) katsayısı ve Barlett Küresellik (Sphericity) Testi ile hesaplanmıştır. Verilerin faktör analizine uygunluğu için KMO'nun .60'dan yüksek ve Barlett Kürsellik (Sphericity) Testinin anlamlı çıkması gerekir (Büyüköztürk, 2012:126). DYÖ için 158 öğrenci üzerinde yapılan faktör analizinde KMO .878 çıkmıştır. Bu durum örneklem büyüklüğünün faktör analizi için uygun olduğunu göstermektedir. Barlett testi sonucu da anlamlı bulunmuştur [X2 $=6402.908$ p<.01]. Bu veriler, faktör çıkartmak için uygun olduğunu göstermektedir. Kaiser-Meyer-Olkin (KMO) katsayısı ve Barlett testlerinin sonuçları Tablo-2'de sunulmuştur.

Tablo-2. Dinsel Yaşayış Ölçeğinin Kaiser-Meyer-Olkin (KMO) ve Barlett Testlerinin Sonuçları

\begin{tabular}{ll}
\hline Kaiser-Meyer-Olkin Örneklem Uyum Ölçüsü & .878 \\
\hline \multirow{2}{*}{ Barlet Küresellik Testi } & $\mathrm{X}^{2}=6402.908$ \\
& $\mathrm{p}=.000$ \\
\hline
\end{tabular}




\subsection{Açımlayıcı Faktör Analiz Çalışmaları}

Öğrencilerin dinsel yaşayış düzeylerini belirlemek için hazırlanan ve 158 öğrenciye uygulanan 36 maddelik taslak ölçme aracının, en az sayıda maddeyle en fazla özelliği ölçebilen bir araca dönüştürülmesi için yapılan açımlayıcı faktör analizi sonucunda öz değeri 1'den büyük olan 3 faktör belirlenmiştir. Birinci faktörün özdeğerinin 13.385 olduğu ve toplam varyansın \%29.265'ini; ikinci faktörün özdeğerinin 6.319 olduğu ve toplam varyansın \%20.528'ini; ve üçüncü faktörün özdeğerinin 3.550 olduğu ve toplam varyansın \%14.580'ini açıkladığı görülmektedir. Her üç faktörün birlikte açıkladıkları toplam varyans ise \%64.594'tür. Tabachnick ve Fidell'e (2007) göre, ölçek geliştirme çalışmalarında açıklanan toplam varyansın \%50 ve üzeri değerlerin kabul edilebilir olduğunu belirtmektedir.

Tablo-3. Dinsel Yaşayış Ölçeğinin Döndürülmüş Temel Bileşenler Analizi Tablosu

\begin{tabular}{|l|l|l|l|l|l|}
\hline & \multirow{2}{*}{$\begin{array}{l}\text { Madde } \\
\text { Numarası }\end{array}$} & $\begin{array}{l}\text { Faktör } \\
\text { Ortak } \\
\text { Varyansı }\end{array}$ & $\begin{array}{l}\text { Döndürme Sonrası } \\
\text { Yükü }\end{array}$ & $\begin{array}{l}\text {.Faktörde } \\
\text { törde } \\
\text { Yükü }\end{array}$ & $\begin{array}{l}\text { 3.Fakt } \\
\text { örde } \\
\text { Yükü }\end{array}$ \\
\hline $\mathbf{1}$ & Allah yaptığımız her şeyi bilir. & 0.960 & 0.970 & & \\
\hline $\mathbf{2}$ & $\begin{array}{l}\text { Mahşer gününde herkes yaptıkla- } \\
\text { rından dolayı hesaba çekilecektir. }\end{array}$ & 0.951 & 0.962 & & \\
\hline $\mathbf{3}$ & $\begin{array}{l}\text { Kuran-ı Kerim'in haber verdiği her } \\
\text { şey doğrudur. }\end{array}$ & 0.928 & 0.953 & & \\
\hline $\mathbf{4}$ & $\begin{array}{l}\text { Kur'an Allah'ın gönderdiği kutsal } \\
\text { bir kitaptır. }\end{array}$ & 0.917 & 0.950 & & \\
\hline $\mathbf{5}$ & Allah'ın var olduğuna inanıyorum. & 0.891 & 0.938 & & \\
\hline $\mathbf{6}$ & Kur'an, Allah'ın emirlerini bildirir. & 0.889 & 0.928 & & \\
\hline $\mathbf{7}$ & $\begin{array}{l}\text { Meleklerin var olduğuna inanıyo- } \\
\text { rum. }\end{array}$ & 0.878 & 0.916 & & \\
\hline $\mathbf{8}$ & $\begin{array}{l}\text { Öldükten sonra ahiret denen } \\
\text { sonsuz bir hayat olacaktır. }\end{array}$ & 0.811 & 0.888 & & \\
\hline $\mathbf{9}$ & $\begin{array}{l}\text { Kâinattaki her şey Allah tarafından } \\
\text { yaratılmıştır. }\end{array}$ & 0.803 & 0.882 & & \\
\hline $\mathbf{1 0}$ & Kıyamet günü vardır. & 0.800 & 0.874 & & \\
\hline $\mathbf{1 1}$ & $\begin{array}{l}\text { Kur'an günümüze kadar aynen } \\
\text { korunmuştur. }\end{array}$ & 0.786 & 0.849 & 0.820 & \\
\hline $\mathbf{1 2}$ & $\begin{array}{l}\text { Hz. Muhammed'in Allah'ın pey- } \\
\text { gamberi olduğuna inanıyorum. }\end{array}$ & 0.685 & 0.791 & & \\
\hline $\mathbf{1 3}$ & $\begin{array}{l}\text { İnsanları aldatmak dini inancıma } \\
\text { aykırı olduğu için kimseyi aldat- } \\
\text { mamaya özen gösteriyorum. }\end{array}$ & 0.747 & & & \\
\hline $\mathbf{1 4}$ & $\begin{array}{l}\text { Kumar oynamak günah olduğu } \\
\text { çin kumar oynamaktan kaçınıyo- } \\
\text { rum. }\end{array}$ & 0.700 & & & \\
\hline
\end{tabular}




\begin{tabular}{|c|c|c|c|c|}
\hline 15 & $\begin{array}{l}\text { Bana emanet edilen bir şeyi inan- } \\
\text { cım gereği her zaman korurum. }\end{array}$ & 0.697 & 0.816 & \\
\hline 16 & $\begin{array}{l}\text { Dini inancıma göre doğru sözlü } \\
\text { olmak gerektiğinden, doğru söy- } \\
\text { lemeye gayret ediyorum. }\end{array}$ & 0.762 & 0.775 & \\
\hline 17 & $\begin{array}{l}\text { Rüşvet alıp-vermek günah olduğu } \\
\text { için rüşvet alıp-vermekten kaçını- } \\
\text { yorum. }\end{array}$ & 0.645 & 0.773 & \\
\hline 18 & $\begin{array}{l}\text { Anne-babaya iyi davranmayı Allah } \\
\text { emrettiği için anne-babama iyi } \\
\text { davranıyorum. }\end{array}$ & 0.628 & 0.768 & \\
\hline 19 & $\begin{array}{l}\text { Söz verildiği zaman sözünde } \\
\text { durmak dini bir kural olduğundan } \\
\text { verdiğim sözü tutuyorum. }\end{array}$ & 0.617 & 0.764 & \\
\hline 20 & $\begin{array}{l}\text { İnancım gereği yoksullara yardım } \\
\text { ediyorum. }\end{array}$ & 0.623 & 0.758 & \\
\hline 21 & $\begin{array}{l}\text { İnsanlara iyi davranmak din tara- } \\
\text { fından tavsiye edildiği için insanla- } \\
\text { ra iyi davranıyorum. }\end{array}$ & 0.535 & 0.709 & \\
\hline 22 & $\begin{array}{l}\text { Evlilik dışı cinsel ilişki (zina) dinde } \\
\text { yasaklandığı için bu tür ilişkiden } \\
\text { kaçınıyorum. }\end{array}$ & 0.500 & 0.690 & \\
\hline 23 & $\begin{array}{l}\text { Dinde yasak edildiği için uyuştu- } \\
\text { rucu kullanmamaya özen gösteri- } \\
\text { yorum. }\end{array}$ & 0.462 & 0.665 & \\
\hline 24 & $\begin{array}{l}\text { Yardım talep edenlere Allah rızası } \\
\text { için yardım ediyorum. }\end{array}$ & 0.538 & 0.638 & \\
\hline 25 & Namazlarımı kılıyorum & 0.569 & & 0.748 \\
\hline 26 & $\begin{array}{l}\text { Herhangi bir engel olmadığı süre- } \\
\text { ce ibadetlerimi yapıyorum. }\end{array}$ & 0.614 & & 0.743 \\
\hline 27 & $\begin{array}{l}\text { Farz ibadetlerin dışında da ibadet } \\
\text { ediyorum. }\end{array}$ & 0.568 & & 0.722 \\
\hline 28 & $\begin{array}{l}\text { Televizyonda yayınlanan dinsel } \\
\text { programları seyrediyorum. }\end{array}$ & 0.520 & & 0.692 \\
\hline 29 & Dinsel yayınlar okuyorum. & 0.490 & & 0.687 \\
\hline 30 & $\begin{array}{l}\mathrm{Hz} \text {. Peygamberi (Hz. Muhammed) } \\
\text { anma etkinliklerine katılıyorum. }\end{array}$ & 0.428 & & 0.649 \\
\hline 31 & Kur'an-ı Kerim okuyorum. & 0.456 & & 0.646 \\
\hline 32 & $\begin{array}{l}\text { Kutsal gün ve gecelerde dua ve } \\
\text { ibadet yapıyorum. }\end{array}$ & 0.455 & & 0.621 \\
\hline 33 & $\begin{array}{l}\text { Ramazan ayı dışında da oruç } \\
\text { tutuyorum. }\end{array}$ & 0.375 & & 0.595 \\
\hline 34 & Dua ediyorum. & 0.467 & & 0.521 \\
\hline 35 & $\begin{array}{l}\text { Mazeretlerim dışında } \\
\text { ayında oruç tutuyorum. }\end{array}$ & 0.262 & & 0.493 \\
\hline 36 & Allah'ı zikrediyorum. & 0.294 & & 0.390 \\
\hline
\end{tabular}

Tablo-3 incelendiğinde faktör ortak varyans değerlerinin 0.262-0.960 ve döndürülmüş faktör yük değerlerin 0.390-0.970 arasında değiştiği görülmektedir. 


\subsection{Doğrulayıcı Faktör Analiz Çalışmaları}

Üç faktörlü otuz altı maddelik "Dinsel Yaşayış Ölçeği"nin kuramsal yapısını test etmek için "Doğrulayıcı Faktör Analizi-DFA (Confirmatory Factor Analysis-CFA)" yapılmıştır. Dinsel Yaşayış Ölçeğinin "Doğrulayıcı Faktör Analiz-DFA" sonuçları Tablo-4'te görülmektedir.

Tablo-4. Dinsel Yaşayış Ölçeğinin Doğrulayıcı Faktör Analiz Sonuçları

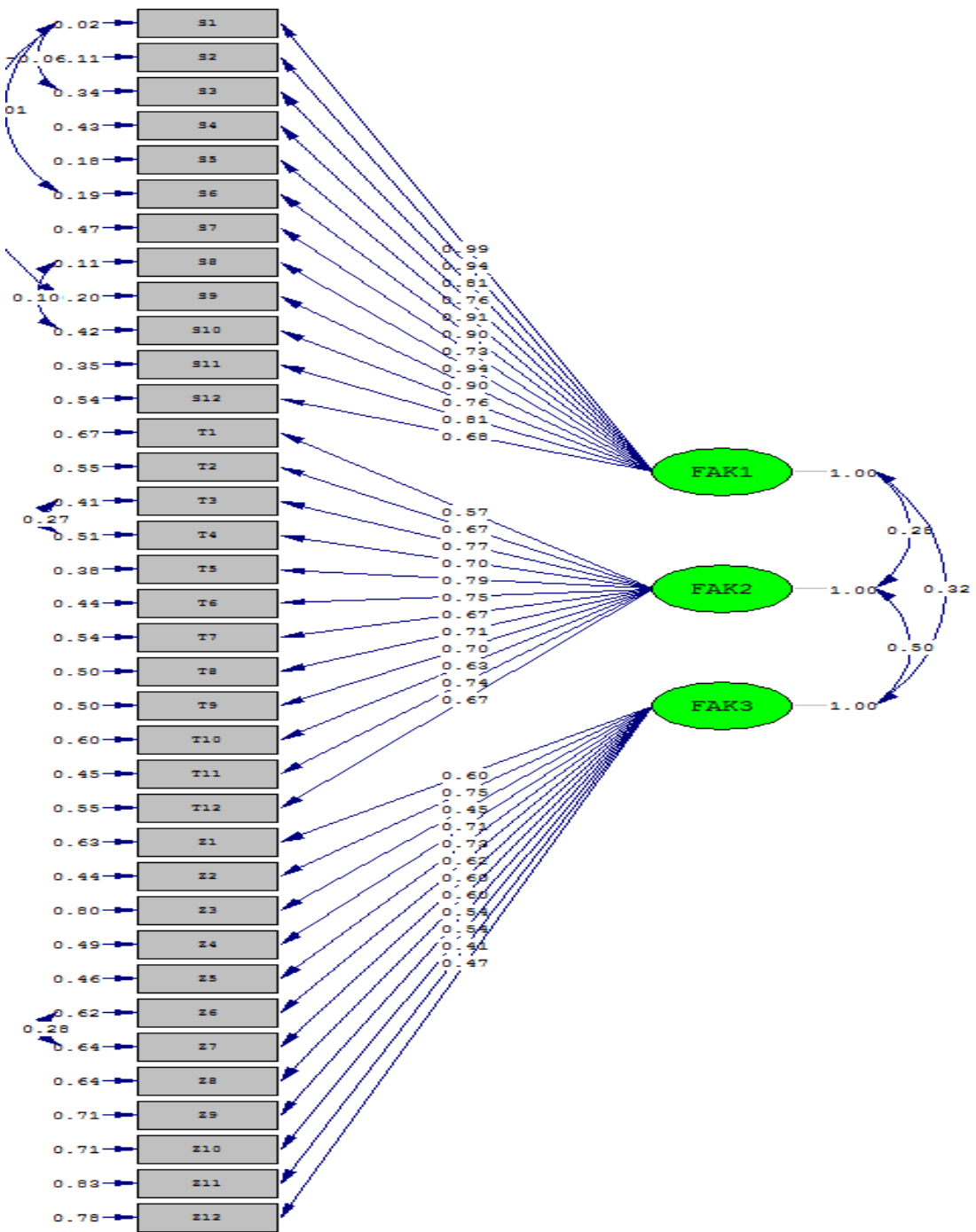


Literatürde DFA'da sınanan modelin uyum yeterliliğini belirlemek için pek çok uyum indeksi kullanılmaktadır (Dağlı ve Baysal, 2016:1527-1258). Analizde, Karşılaştırmalı Uyum İndeksi (Comparative Fit Index-CFI), Ki-Kare (Chi-square), Serbestlik Derecesi (Degree of Freedom-df), Yaklaşık Hataların Ortalama Kare Kökü (Root Mean Square Error of Approximation-RMSEA), Standart Ortalama Kalanların Kare Kökü (Standardized Root Mean ResidualSRMR), Normlaştırılmış Uyum İndeksi (Normed Fit Index-NFI) ve Normlaştırılmamış Uyum İndeksi (Non-Normed Fit Index-NNFI) değerleri kullanılmıştır. Beauducel ve Wittman'a (2005) göre bu değerler DFA sonuçlarını değerlendirmede geçerli bilgiler sunmaktadır. DFA ile oluşturulan modellerin uyum değerleri Tablo-5'te görülmektedir.

Tablo-5. Doğrulayıcı Faktör Analizi-DFA Uyum Değerleri

\begin{tabular}{|l|l|l|l|l|l|l|l|l|}
\hline Analiz & $X^{2}$ & $d f$ & $X^{2} / d f$ & RMSEA & SRMR & NFI & NNFI & CFI \\
\hline Sonuç & 1134,01 & 585 & 1,93 & 0,07 & 0,07 & 0,91 & 0,95 & 0,95 \\
\hline
\end{tabular}

Modelin uyum indekslerinden birisi olan $X^{2} /$ sd'nin değeri 1.93 olarak bulunmuştur. Ayrıca uyum indekslerinden olan NFI değeri 0.91, NNFI değeri 0.95, CFI değeri 0.95 ve SRMR değeri 0.07, RMSEA değeri 0.07 olduğu görülmüştür. Bu değerlerin "Doğrulayıcı Faktör Analizi-DFA" sonucunda ölçeğin faktör yapısının uyumunun iyi olduğunu göstermektedir.

\subsection{Güvenirlik}

Bu çalışmada "Dinsel Yaşayış Ölçeği"nin güvenirliği, iç tutarlık (Cronbach Alpha) katsayısı ile hesaplanmıştır. Ölçeği oluşturan maddelerin iç tutarlık katsayısı 0.930 olarak bulunmuştur. Ayrıca her bir faktörün iç tutarlık katsayısı kendi içerisinde hesaplanmıştır. Buna göre Faktör-1, Faktör-2 ve Faktör-3'ün iç tutarlılık katsayısı sırasıyla $0.982,0.937$ ve 0.875 olarak hesaplanmıştır. Güvenirlilik katsayısının 0.70 ve daha yüksek olması test puanlarının güvenirliği için yeterli görülmektedir (Büyüköztürk, 2012). 


\section{Sonuç ve Tartışma}

Bu çalışmada, daha önce Kayıklık (2003) tarafından geliştirilen "Dinsel Yaşayış Ölçeği"ni bazı analizlerle revize edilmesi amaçlanmıştır. Yapılan analizler sonucunda ölçeğin üç faktör ve her faktör on iki madde olmak üzere toplam otuz altı maddeden oluştuğu görülmüştür.

Kapsam geçerlik çalışması için alanında uzman olan dokuz araştırmacının görüşüne başvurulmuş ve elde edilen analizler sonucunda ölçeğin "Kapsam Geçerlik İndeksi (KGi)" 1.17 olarak bulunmuştur.

Üç faktörlü DYÖ için yapılan açımlayıcı faktör analizi sonucunda ölçeğin döndürülmüş faktör yük değerleri 0.390- 0.970 arasında değişmektedir. Ayrıca ölçeğin inanç faktörü toplam varyansın \%29.265'ini, ahlâk faktörü \%20.528'ini ve ibadet faktörü \%14.801'ini açıklamaktadır. Her üç faktörün birlikte açıkladığı toplam varyans ise \%64.594'tür.

Kayıklık (2003) tarafından geliştirilen "Dinsel Yaşayış Ölçeği"nin on bir maddeden oluşan inanç boyutu maddelerinin faktör yük değerleri 0.44 ile 0.95 , dokuz maddeden oluşan ahlâk boyutu maddelerinin faktör yük değerleri 0.53 ile 0.71 , ve on üç maddeden oluşan ibadet boyutu maddelerinin faktör yük değerleri ise 0.36 ile 0.85, arasında değişmektedir. Arslan (2010:30) "Paranormal İnanç Ölçeği" çalışmasında maddelerin faktör yüklerini, 0.42 ve 0.86 arasında ve bu maddelerin toplam varyansın \%58.7'sini açıkladığını bulmuştur. Ayrıca Ok (2011:541-542) çalışmasında "Ok-Dini Tutum Ölçeği"nin toplam varyansın \%86'sını açıkladığını bulmuştur. Dindarlık, inanç gibi ölçeklerde benzer bulgular başka çalışmalarda da rastlanmıştır (Uysal, 1995:264; Kaya, 1998; Onay, 2004; Yıldız, 2006).

Üç faktörlü otuz altı maddelik "Dinsel Yaşayış Ölçeği"nin kuramsal yapısını test etmek için "Doğrulayıcı Faktör Analizi" yapıımıştır. Modelin uyum indekslerinden birisi olan X²/sd'nin değeri 1.71, NFI değeri 0.91, NNFI değeri 0.95, CFI değeri 0.96 ve SRMR değeri 0.07 , RMSEA değeri 0.06 olarak görülmüştür.

Ölçeğin güvenirlik analizi sonucunda iç tutarlılık katsayısı 0.930 olarak bulunmuştur. Bununla birlikte inanç, ahlâk ve ibadet alt faktörlerinin içi tutarlılık katsayıları sırasıyla $0.982,0.937$ ve 0.875 olduğu görülmüştür. Arslan (2010:37) yaptığı "Paranormal İnanç Ölçeği" çalışmasında ise iç tutarlılık katsayısının 0.85 olarak bulmuştur. Ayrıca Mutlu (1989:195) "Dindarlık Ölçeği"nin iç tutarlılık katsayısını 0.94, Yapıcı (2002:115) "Dini Dogmatizm Ölçeği"nin iç tutarlılık katsayısını 0.91; Türküm (2003:43) "Akılcı Olmayan İnanç Ölçeği"nin 
iç tutarlılık katsayısını 0.84 ve Yapıcı (2006:84) "Dinin Etkisini Hissetme Ölçeği"nin iç tutarlılık katsayısını 0.95 olarak bulmuştur.

Bu analizler sonucunda ölçeğin alt boyutlarıyla beraber yüksek düzeyde iç tutarlılığa sahip olduğu, açımlayıcı ve doğrulayıcı faktör geçerliliği bulunduğu görülmüştür. Böylece DYÖ'nün revize edilmesi neticesinde geçerli ve güvenilir bir ölçek olduğu ortaya çıkmıştır.

\section{Kaynakça}

Almeida, A. M., Neto, F. L. ve Koenig, H. G. (2006). Religiousness and mental health: A review. Journal of Rev Bras Psiquiatr, 28 (3), 242-250.

Arslan, M. (2010). Paranormal inanç ölçeğinin Türkçe versiyonunun geliştirilmesi: Geçerlik ve güvenirlik çalışması. I. Ü. Illahiyat Fakültesi Dergisi, 1(2), 23-40.

Beauducel, A. \& Wittmann, W. W. (2005). Simulation study on fit indexes in cfa based on data with slightly distorted simple structure. Structural Equation Modelling: A Multidisciplinary Journal, 12, 41-75.

Beckwith, H. D. \& MorrowJ, A. (2005). Sexual attitudes of college students: the impact of religiosity and spirituality. College Student Journal.

Büyüköztürk, Ş. (2012). Veri analizi el kitabı. İstatistik, araştırma deseni SPSS uygulamaları ve yorum. Ankara: Pegam Akademi Yayınları.

Cirhinlioğlu, F. G. (2010). Din psikolojisi. Ankara: Nobel Yayınları.

Cotton, S., Larkin, E., Hoopes, A., Cromer, B. A. ve Rosenthal, S. L. (2005). The impact of adolescent spirituality on depressive symptoms and health risk behaviors. Journal of Adolescent Health, 36 (6).

Dağlı, A., Baysal, N. (2016). Yaşam doyumu ölçeğinin Türkçe'ye uyarlanması: Geçerlik ve güvenirlik çalışması. Elektronik Sosyal Bilimler Dergisi, 15 (59), 1250-1262.

Fraenkel, J. R., Wallen, N. E. (2003). How to design and evaluate research in education. New York: McGraw-Hill.

Hökelekli, H. (2010). Din psikolojisine giriş. İstanbul: Dem Yayınları.

Hökelekli, H. (2013). Din psikolojisi. Ankara: Türkiye Diyanet Vakfı Yayınları.

Hyman, C. ve Handal, P.J. (2006). Definitions and evaluation of religion and spiritualty items by religious professionals: A plot study. Journal of Religion and Health, 45 (2), 264-282.

Karasar, N. (2004). Bilimsel araştırma yöntemleri. Ankara: Nobel Yayın Dağıtım.

Kaya, M. (1998). Din eğitiminde iletişim ve dinî tutum. Samsun: Etüt Yayınları. 
Kayıklık, H. (2000). Dini yaşayış biçimleri: Psikolojik temelleri açısından bir değerlendirme (Yayınlanmamış Doktora Tezi). Dokuz Eylül Üniversitesi, İzmir.

Kayıklık, H. (2003). Orta yaş ve yaşlııkta dinsel eğilimler. Adana: Baki Yayınları.

Kayıklık, H. (2011). Din psikolojisi. Adana: Karahan Yayınevi.

Köktaş, M. E. (1993). Türkiye'de dini hayat. İstanbul: İşaret Yayınları.

Murata, S. Chittick, W. C. (2012). İslâm'ın vizyonu (Turan Koç, Çev.). İstanbul: İnsan Yayınları.

Mutlu, K. (1989). Bir dindarlık ölçeği sosyolojide yöntem üzerine bir tartışma. İslami Araştırmalar Dergisi, 3(4), 194-199.

Ok, Ü. (2011). Dini tutum ölçeği: Ölçek geliştirme ve geçerlik çalışması. Uluslararası Insan Bilimleri Dergisi, 8(2), 528-549.

Onay, A. (2001). Dindarlık ölçme çalışmaları: Dindarlık ölçümünde üç farklı yaklaşım ve ölçmenin esasları. İslami Araştırmalar Dergisi, 14(3-4), 439-449.

Onay, A. (2004). Dindarlık, etkileşim ve değişim. İstanbul: DEM.

Peker, H. (2011). Din psikolojisi. İstanbul: Çamlıca Yayınları.

Şentürk. H. (2013). Din psikolojisine giriş. İstanbul: İz Yayıncılık.

Tabachnick, B. G., Fidell, L. S. (2007). Using multivariate statistics. Boston: Allyn ve Bacon.

Tablamcıoğlu, M. (1962). Yaşlara göre dini yaşayışın şiddet ve kesâfeti üzerine bir anket denemesi. A. Ü. I. F. Dergisi, 141-151.

Tarhan, N. (2013). Inanç psikolojisi. İstanbul: Timaş Yayınları.

Türküm, A. S. (2003). Akılcı olmayan inanç ölçeğinin geliştirilmesi ve kısaltma çalışmaları. Türk Psikolojik Danışma ve Rehberlik Dergisi, 2(19), 41-47.

Uysal, V. (1995). İslami dindarlık ölçeği üzerine bir pilot çalışma. İslami Araştırmalar, 8, 263-271.

Uysal, V. (1996). Din Psikolojisi Açısından Dini Tutum Davranış ve Şahsiyet Özellikleri. M. Ü. İlahiyat Fakültesi Vakfı Yayınları: İstanbul.

Yapıcı, A. (2002). Dini yaşayışın farklı görüntüleri ve dogmatik dindarlık. Ç. Ü. Illahiyat Fakültesi Dergisi, 2(2), 75-118.

Yapıcı, A. (2006). Yeni bir dindarlık ölçeği ve üniversiteli gençlerin dinin etkisini hissetme düzeyi: Çukurova Üniversitesi Örneği. Ç. Ü. İlahiyat Fakültesi Dergisi, 6(1), 65-115.

Yapıcı, A. (2013). Ruh sağlığı ve din: Psiko-sosyal uyum ve dindarlık. Adana: Karahan Yayınevi.

Yavuz, K. (2013). Günümüzde inancın psikolojisi. İstanbul: Boğaziçi Yayınları. 
Yıldız, M. (2006). Ölüm kaygısı ve dindarlık. İzmir: İzmir İlahiyat Vakfı Yay.

Yılmaz, A. Tan, E. (2016). The effect of student achievement in cognitive level of peer teaching methods in science teaching. Journal of Currents Researchs on Social Sciences (JoCReSS), 6 (2), 185-200.

Yılmaz, A., Fakirullahöğlu, Z. (2016). Standards and procedures for the accreditation of science teacher training program. Journal of Currents $R e$ searchs on Social Sciences (JoCReSS), 6 (2), 219-238. 
Ek-1. Dinsel Yaşayış Ölçeği (DYÖ) Maddeleri

\begin{tabular}{|c|c|c|c|c|c|c|c|c|}
\hline & $\begin{array}{l}\text { Aşağıdaki ifadelerden her birini } \\
\text { okuduktan sonra, bu ifadeye ne } \\
\text { ölçüde katıldığınızı gösteren sütuna } \\
\text { ait olan ve ifadenin hizasında kutu- } \\
\text { cuğun içini }(X) \text { işaretini koyarak } \\
\text { belirtiniz. }\end{array}$ & 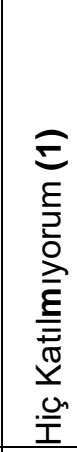 & 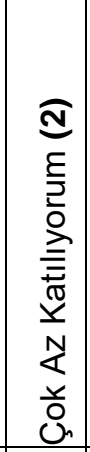 & 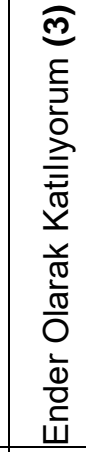 & 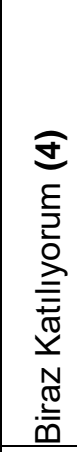 & 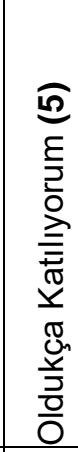 & 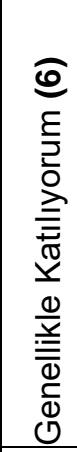 & 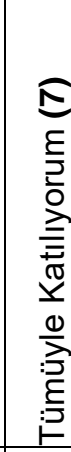 \\
\hline 1 & Allah yaptığımız her şeyi bilir. & () & () & () & $($ ) & () & () & () \\
\hline 2 & $\begin{array}{l}\text { Mahşer gününde herkes yaptıkla- } \\
\text { rından dolayı hesaba çekilecektir. }\end{array}$ & $($ ) & $($ ) & $($ ) & $($ ) & $($ ) & $($ ) & $($ ) \\
\hline 3 & $\begin{array}{l}\text { Kuran-ı Kerim'in haber verdiği her } \\
\text { şey doğrudur. }\end{array}$ & $($ ) & $($ ) & $($ ) & $($ ) & $($ ) & $($ ) & $($ ) \\
\hline 4 & $\begin{array}{l}\text { Kur'an Allah'ın gönderdiği kutsal bir } \\
\text { kitaptır. }\end{array}$ & $($ ) & $($ ) & $($ ) & $($ ) & $($ ) & $($ ) & $($ ) \\
\hline 5 & Allah'ın var olduğuna inanıyorum. & () & () & () & () & () & () & () \\
\hline 6 & Kur'an, Allah'ın emirlerini bildirir. & $($ ) & () & $($ ) & () & () & () & () \\
\hline 7 & $\begin{array}{l}\text { Meleklerin var olduğuna inanıyo- } \\
\text { rum. }\end{array}$ & $($ ) & ( ) & $($ ) & $($ ) & ( ) & $($ ) & $($ ) \\
\hline 8 & $\begin{array}{l}\text { Öldükten sonra ahiret denen son- } \\
\text { suz bir hayat olacaktır. }\end{array}$ & $($ ) & $($ ( ) & $($ ) & $($ ) & $($ ) & $($ ) & $($ ) \\
\hline 9 & $\begin{array}{l}\text { Kâinattaki her şey Allah tarafından } \\
\text { yaratılmıştır. }\end{array}$ & $($ ) & $($ ) & $($ ) & $($ ) & $($ ) & $($ ) & () \\
\hline 10 & Kıyamet günü vardır. & $($ ) & () & $($ ) & $($ ) & $($ ) & $($ ) & () \\
\hline 11 & $\begin{array}{l}\text { Kur'an günümüze kadar aynen } \\
\text { korunmuştur. }\end{array}$ & $($ ) & ( ) & ( ) & $($ ) & $($ ) & $($ ) & $($ ) \\
\hline 12 & $\begin{array}{l}\text { Hz. Muhammed'in Allah'ın pey- } \\
\text { gamberi olduğuna inanıyorum. }\end{array}$ & ( ) & ( ) & $($ ) & ( ) & ( ) & $($ ) & ( ) \\
\hline
\end{tabular}




\begin{tabular}{|c|c|c|c|c|c|c|c|c|}
\hline & & 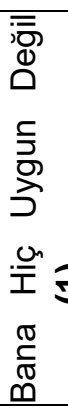 & 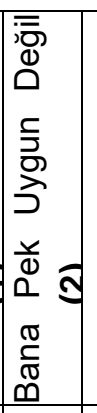 & 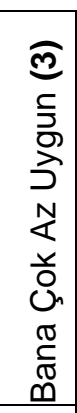 & 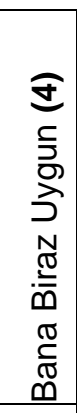 & 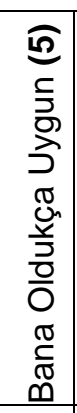 & 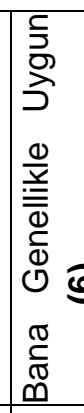 & 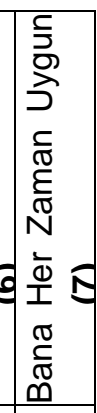 \\
\hline 13 & $\begin{array}{l}\text { İnsanları aldatmak dini inancıma } \\
\text { aykırı olduğu için kimseyi aldat- } \\
\text { mamaya özen gösteriyorum. }\end{array}$ & ( ) & ( ) & ( ) & ( ) & ( ) & ( ) & ( ) \\
\hline 14 & $\begin{array}{l}\text { Kumar oynamak günah olduğu } \\
\text { için kumar oynamaktan kaçınıyo- } \\
\text { rum. }\end{array}$ & ( ) & ( ) & ( ) & ( ) & ( ) & ( ) & ( ) \\
\hline 15 & $\begin{array}{l}\text { Bana emanet edilen bir şeyi inan- } \\
\text { cım gereği her zaman korurum. }\end{array}$ & $($ ) & ( ) & ( ) & ( ) & ( ) & ( ) & ( ) \\
\hline 16 & $\begin{array}{l}\text { Dini inancıma göre doğru sözlü } \\
\text { olmak gerektiğinden, doğru söy- } \\
\text { lemeye gayret ediyorum. }\end{array}$ & $($ ) & ( ) & ( ) & ( ) & ( ) & ( ) & ( ) \\
\hline 17 & $\begin{array}{l}\text { Rüşvet alıp-vermek günah olduğu } \\
\text { için rüşvet alıp-vermekten kaçını- } \\
\text { yorum. }\end{array}$ & $($ ) & ( ) & ( ) & ( ) & ( ) & ( ) & ( ) \\
\hline 18 & $\begin{array}{l}\text { Anne-babaya iyi davranmayı Allah } \\
\text { emrettiği için anne-babama iyi } \\
\text { davranıyorum. }\end{array}$ & $($ ) & ( ) & ( ) & ( ) & ( ) & ( ) & ( ) \\
\hline 19 & $\begin{array}{l}\text { Söz verildiği zaman sözünde } \\
\text { durmak dini bir kural olduğundan } \\
\text { verdiğim sözü tutuyorum. }\end{array}$ & $($ ) & ( ) & ( ) & ( ) & ( ) & ( ) & ( ) \\
\hline 20 & $\begin{array}{l}\text { İnancım gereği yoksullara yardım } \\
\text { ediyorum. }\end{array}$ & $($ ) & ( ) & ( ) & ( ) & ( ) & ( ) & ( ) \\
\hline 21 & $\begin{array}{l}\text { İnsanlara iyi davranmak din tara- } \\
\text { fından tavsiye edildiği için insanla- } \\
\text { ra iyi davranıyorum. }\end{array}$ & $($ ) & $($ ) & ( ) & ( ) & ( ) & ( ) & ( ) \\
\hline 22 & $\begin{array}{l}\text { Evlilik dışı cinsel ilişki (zina) dinde } \\
\text { yasaklandığı için bu tür ilişkiden } \\
\text { kaçınıyorum. }\end{array}$ & $($ ) & ( ) & ( ) & ( ) & ( ) & ( ) & ( ) \\
\hline 23 & $\begin{array}{l}\text { Dinde yasak edildiği için uyuştu- } \\
\text { rucu kullanmamaya özen gösteri- } \\
\text { yorum. }\end{array}$ & () & ( ) & ( ) & ( ) & ( ) & ( ) & ( ) \\
\hline
\end{tabular}




\begin{tabular}{|l|l|l|l|l|l|l|l|l|}
\hline $\mathbf{2 4}$ & $\begin{array}{l}\text { Yardım talep edenlere Allah rızası } \\
\text { için yardım ediyorum. }\end{array}$ & ( ) & ( ) & ( ) & ( ) & ( ) & ( ) & ( ) \\
\hline $\mathbf{2 5}$ & Namazlarımı kııyorum & ( ) & ( ) & ( ) & ( ) & ( ) & ( ) & ( ) \\
\hline $\mathbf{2 6}$ & $\begin{array}{l}\text { Herhangi bir engel olmadığı süre- } \\
\text { ce ibadetlerimi yapıyorum. }\end{array}$ & ( ) & ( ) & ( ) & ( ) & ( ) & ( ) & ( ) \\
\hline $\mathbf{2 7}$ & $\begin{array}{l}\text { Farz ibadetlerin dışında da ibadet } \\
\text { ediyorum. }\end{array}$ & ( ) & ( ) & ( ) & ( ) & ( ) & ( ) & ( ) \\
\hline $\mathbf{2 8}$ & $\begin{array}{l}\text { Televizyonda yayınlanan dinsel } \\
\text { programları seyrediyorum. }\end{array}$ & ( ) & ( ) & ( ) & ( ) & ( ) & ( ) & ( ) \\
\hline $\mathbf{2 9}$ & Dinsel yayınlar okuyorum. & ( ) & ( ) & ( ) & ( ) & ( ) & ( ) & ( ) \\
\hline $\mathbf{3 0}$ & $\begin{array}{l}\text { Hz. Peygamberi (Hz. Muhammed) } \\
\text { anma etkinliklerine katıııorum. }\end{array}$ & ( ) & ( ) & ( ) & ( ) & ( ) & ( ) & ( ) \\
\hline $\mathbf{3 1}$ & Kur'an-ı Kerim okuyorum. & ( ) & ( ) & ( ) & ( ) & ( ) & ( ) & ( ) \\
\hline $\mathbf{3 2}$ & $\begin{array}{l}\text { Kutsal gün ve gecelerde dua ve } \\
\text { ibadet yapıyorum. }\end{array}$ & ( ) & ( ) & ( ) & ( ) & ( ) & ( ) & ( ) \\
\hline $\mathbf{3 3}$ & $\begin{array}{l}\text { Ramazan ayı dışında da oruç } \\
\text { tutuyorum. }\end{array}$ & ( ) & ( ) & ( ) & ( ) & ( ) & ( ) & ( ) \\
\hline $\mathbf{3 4}$ & Dua ediyorum. & ( ) & ( ) & ( ) & ( ) & ( ) & ( ) & ( ) \\
\hline $\mathbf{3 5}$ & $\begin{array}{l}\text { Mazeretlerim dışında Ramazan } \\
\text { ayında oruç tutuyorum. }\end{array}$ & ( ) & ( ) & ( ) & ( ) & ( ) & ( ) & ( ) \\
\hline $\mathbf{3 6}$ & Allah'ı zikrediyorum. & ( ) & ( ) & ( ) & ( ) & ( ) & ( ) & ( ) \\
\hline
\end{tabular}




\section{Religious Life Scale: A Study of Validity and Reliability}

Citation / @-Kayıklık, H.-Kalgı, M. E. (2017). Religious Life Scale: A Study of Validity and Reliability, Çukurova University Journal of Faculty of Divinity 17 (1), 1-19.

Abstract- The aim of this study is to revise the "Religious Lifestyle Scale", which was developed by Kayıklık (2003). During the revision process, the number of the scale factors (3 factors) have been preserved, but by adding new questions to the scale and making changes to some questions based on specialist opinions, both an analysis of the analytical and corroborative factors has been carried out for the validity of the scale and the co-efficient of its internal consistency (Cronbach-alpha) was calculated in order to analyse its reliability. In the study, the general polling model, one of the quantitative research methods, was used. The data of the study was taken from $158 \mathrm{stu}-$ dents (103 girls, 55 boys) who study at the Karacadağ Anatolian Lycee in the district of Siverek in Şanlıurfa province and they were selected using a basic random selection method. In the exploratory factor analysis of the questions that make up the Religious Life Scale $(R L S)$, it was observed that the values of the common factor variance ranged between 0.262-0.960 and the values of the rotated factor loading between 0.390-0.970. Furthermore, in the confirmatory factor analysis carried out on the RLS, it was observed that the value of $X^{2} / s d$, which is one of the fit indices of the model, was 1.93, the NFI value was 0.91 , the NNFI value was 0.95 , the CFI value was 0.95 , the SRMR value was 0.07 , and the RMSEA value was 0.07 . The internal consistency co-efficient was calculated for the reliability analysis. According to this, the internal consistency co-efficient of the scale's questions was found to be 0.930 . The internal consistency co-efficient of Factors 1, 2, and 3 were found to be $0.982,0.937$, and 0.875 respectively. Each statement in the scale was made using a 7 point $\mathrm{Li}$ kert-type scale and each question was calculated by giving one (1) point for the lowest and seven (7) points for the highest. In this way, the lowest score a person can achieve on the thirty-six (36) question $R L S$ is thirty-six (36) points and the highest is two hundred and fiftytwo (252). If a person can get points above the scale's average, they are considered to be religious.

Keywords- Religious life scale, validity, reliability, faith, worship, morals 